\title{
Formation of lipid droplets induced by 2,3-dihydrogeranylgeranoic acid distinct from geranylgeranoic acid ${ }^{\star}$
}

\author{
Yuichi Kodaira ${ }^{1}$, Takeru Kusumoto ${ }^{1}$, Takeshi Takahashi ${ }^{1}$, Yoshihiro Matsumura ${ }^{1}$, \\ Yukino Miyagi ${ }^{1}$, Kyoko Okamoto ${ }^{2}$, Yoshihiro Shidoji ${ }^{2}$ and Hiroshi Sagami ${ }^{1 \bowtie}$ \\ ${ }^{1}$ Institute of Multidisciplinary Research for Advanced Materials, Tohoku University, Sendai, Japan; ${ }^{2}$ Molecular \\ and Cellular Biology, Graduate School of Human Health Sciences, Siebold University of Nagasaki, Nagasaki, \\ Japan
}

Received: 08 August, 2007; revised: 22 November, 2007; accepted: 03 December, 2007 available on-line: 10 December, 2007

\begin{abstract}
Geranylgeranoic acid (GGA) and 2,3-dihydrogeranylgeranoic acid (2,3-diGGA) are geranylgeraniol-derived metabolites (Kodaira et al. (2002) J Biochem 132: 327-334). In the present study, we examined the effects of these acids on HL-60 cells. The cells were differentiated into neutrophils by GGA stimulation like retinoic acid stimulation. In the case of cells stimulated with 2,3-diGGA, neutrophils were not detected, but the formation of lipid droplets was induced. On the other hand, when the cells were cultured in the presence of $0.1 \%$ FBS instead of $10 \%$ FBS, apoptotic cells were induced not only by GGA stimulation but also with 2,3-diGGA. In the latter case, when the cells were cultured in the co-presence of a caspase-3 inhibitor (Ac-DMQD-CHO), the lipid droplets formation was observed in the cells. These results suggest that GGA and 2,3-diGGA are extremely different from each other with respect to their effects on HL-60 cells.
\end{abstract}

Keywords: 2,3-dihydrogeranylgeranoic acid, geranylgeranoic acid, lipid droplets, HL-60, neutrophils

\section{INTRODUCTION}

A number of isoprenylated proteins including Ras, Rho, Rac, and Rab have been established to play an essential role in signal transduction, vesicle transportation, and cell proliferation (Goldstein \& Brown, 1990). One of the isoprenyl precursors is farnesyl diphosphate (FPP), which is also the common intermediate occupying the branch point in mevalonate biosynthetic pathways to cholesterol, dolichol, heme a, and ubiquinone. The other is geranylgeranyl diphosphate (GGPP) synthesized from FPP, which is also a negative regulator for the nuclear receptor (LXRRXR) (Forman et al., 1997). These isoprenyl diphosphates synthesized in the conventional biosynthetic route are also catabolized to their corresponding alcohols, farnesol (FOH) and geranylgeraniol (GGOH). Since these alcohols are incorporated into isoprenylated proteins, a pathway has been proposed as the salvage pathway utilizing $\mathrm{FOH}$ and GGOH for protein isoprenylation (Crick et al., 1997). However, the catabolic pathway from $\mathrm{FOH}$ and GGOH to the corresponding carboxylic acids is also important to understand the entire metabolism of mevalonate.

The enzymatic formation of an isoprenoid acid (farnesoic acid, FA) in liver preparations was first reported by Dituri et al. (1957) and subsequently confirmed and extended by Popjak and his colleagues (Popjak et al., 1959; Christophe \& Popjak, 1964). Fliesler and Schroepfer (1983) also reported

^This paper is dedicated to Professor Tadeusz Chojnacki from the Institute of Biochemistry and Biophysics, Polish Academy of Sciences in Warsaw on the occasion of the 50th anniversary of his scientific activity and 75th birthday.

$\square$ Corresponding author: Hiroshi Sagami, Institute of Multidisciplinary Research for Advanced Materials, Tohoku University, 2-1-1 Katahira, Aoba-ku, Sendai, 980-8577, Japan; tel./fax: (81 22) 217 5620; e-mail: yasagami@tagen.tohoku.ac.jp Abbreviations: Ac-DMQD-CHO, N-acetyl-Asp-Met-Gln-Asp-aldehyde; ATRA, all-trans retinoic acid; 2,3-diGGA, 2,3-dihydrogeranylgeranoic acid; FA, farnesoic acid; FBS, fetal bovine serum; GGA, geranylgeranoic acid; LXR, liver X receptor; NBT, nitro blue tetrazolium; PBS, phosphate-buffered saline; $\mathrm{PGJ}_{2}$, prostaglandin $\mathrm{J}_{2}$; PMA, phorbal myristate acetate; RAR, retinoic acid receptor; RXR, retinoid X receptor; TAG, triacylglycerol. 
the formation of FA, geranylgeranoic acid (GGA) and their derivatives in cell-free homogenates of bovine retinas. Watson and his colleagues (Gonzalez-Pacanowska et al., 1988) have identified several FOH-derived carboxylic acids by experimenting on Drosophila cells. On the other hand, Shidoji et al. (1997) have reported that GGA induces apoptosis in a human hepatoma cell line, but not in mouse primary cultured hepatocytes (Shidoji et al., 1997). They have also demonstrated that GGA and chemically synthesized 4,5-dehydrogeranylgeranoic acid function as potential agonists for RXR and RAR (Araki et al., 1995). Wang et al. (2002) reported that GGA had the ability to induce osteoblast differentiation and to suppress osteoclast formation. Recently, Kodaira et al. (2002) identified 2,3-dihydrogeranylgeranoic acid (2,3-diGGA) by metabolic labelling of GGOH in rat thymic cells and demonstrated that it showed the ability to induce apoptosis in the cells. They also described that 2,3-dihydrofarnesoic acid, which is shorter by one isoprene unit than 2,3-diGGA, did not show such ability. These studies imply that geranylgeranyl compounds such as GGA and 2,3-diGGA operate as molecular signals for the regulation of cell proliferation and cell differentiation.

It is known that HL-60 cells differentiate into neutrophils upon stimulation with retinoids such as retinoic acid and GGA (Araki et al., 1995). Using these cells, we compared the effects of GGA and 2,3-diGGA, which are both mevalonate-derived metabolites. In the presence of $0.1 \%$ fetal bovine serum (FBS) both compounds induced apoptosis of the cells, but in the presence of 10\% FBS GGA induced differentiation of the cells into neutrophils, whereas 2,3-diGGA induced the formation of lipid droplets in the cells. These results are described in this paper. The chemical structures of several compounds used in the present study are shown in Fig. 1.

\section{EXPERIMENTAL PROCEDURE}

Materials. FBS was obtained from Bioindustry. RPMI 1640 medium and Ac-DMQD-CHO were obtained from Nihon Pharmaceutical Co. Ltd. Thin layer silica-gel plates were purchased from Merck. HL-60 cells were obtained from the Cell Resource Center for Biomedical Research, Tohoku University (Japan). (R)-2,3-diGGA was prepared from ethyl $\omega$ $E, E, E$-geranylgeranoate according to the method of Appella et al. (1999). Kits used for the enzymatic determination of cellular cholesterol, triacylglycerol (TAG) and choline-containing phospholipid contents were purchased from Serotec Co. Ltd. Caspase-3 colorimetric assay kits were obtained from Clontech Laboratories, Inc. All other chemicals were of reagent grade.
Cell preparation and culture of leukemia HL-60 cells. HL-60 cells were suspended to a final concentration of $1.0 \times 10^{5}$ to $2.0 \times 10^{6}$ cells $/ \mathrm{ml}$ in RPMI 1640 containing $10 \%$ or $0.1 \%$ FBS. The cells were cultured with the test compounds for $0-5$ days at $37^{\circ} \mathrm{C}$ under an atmosphere of $5 \% \mathrm{CO}_{2}$. Test compounds were prepared as ethanol solution and added to the cell suspension in a final concentration less than $1 \%(\mathrm{v} / \mathrm{v})$.

NBT reduction assay. NBT reduction was done according to the method of Breitman et al. (1980). Briefly, collected cells were incubated in 500 $\mu \mathrm{l}$ of PBS containing $0.2 \% \mathrm{NBT}$ and $200 \mathrm{ng} / \mathrm{ml}$ PMA for $25 \mathrm{~min}$ at $37^{\circ} \mathrm{C}$. After incubation, cells were centrifuged at 1000 r.p.m., and the NBT-positive cells and total cells were counted under a Zeiss microscope.

Morphology of the cells. Cells were observed under phase-contrast and fluorescent microscope. For lipid labeling, cells were treated with $1 \mu \mathrm{M}$ Nile Red (Morjani et al., 2001). After $2 \mathrm{~h}$, the cells were stained with Hoechst 33342.

Analysis of lipids in cells. Cells $\left(4 \times 10^{7}\right.$ cells $)$ treated with test compounds were sonicated in 300 $\mu \mathrm{l}$ of PBS. An aliquot $(250 \mu \mathrm{l})$ was extracted by the Bligh-Dyer method (Bligh et al., 1959). The extracted lipids were dissolved in $50 \mu \mathrm{l}$ of 2-propanol. An aliquot $(10 \mu \mathrm{l})$ was applied to thin-layer silica-gel 60 plates, developed with a solvent system of hexane/ AcOEt $(2: 1, v / v)$, and detected by heating the plates after spraying with $5 \%(\mathrm{w} / \mathrm{v})$ 12-molybdo (VI) phosphoric acid n-hydrate. Another aliquot $(10 \mu \mathrm{l})$ was used for the enzymatic assay of cholesterol, TAG and the phospholipids containing choline content. Molecular weights of TAG and cholesterol were calculated to be 807.34 (tripalmitin) and 386.65 (cholesterol), respectively.

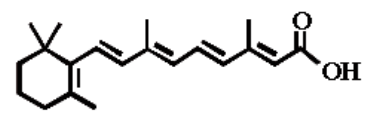

all-trans-Retinoic Acid

(ATRA)

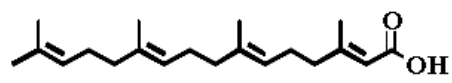

Geranylgeranoic Acid

(GGA)

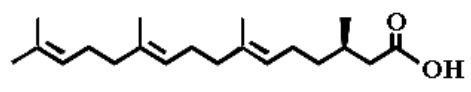

(R)-2,3-Dihydrogeranylgeranoic Acid

(2,3-DiGGA)

Figure 1. Chemical structure of several compounds used in the present study. 
control
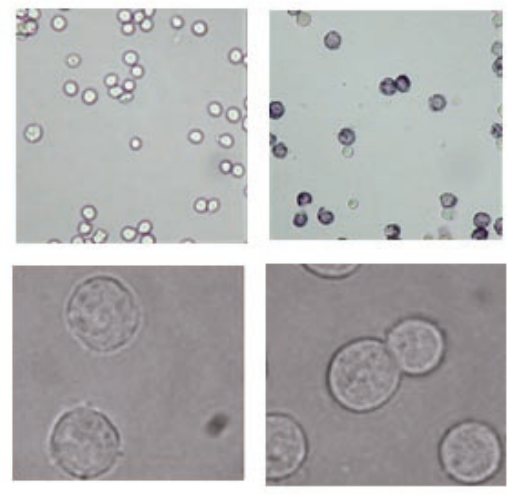

GGA
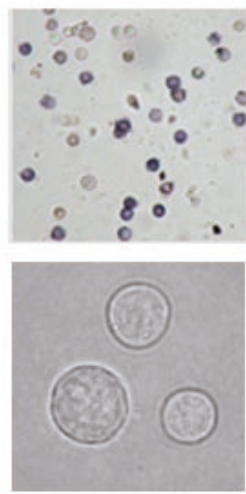

\section{2,3-DiGGA}
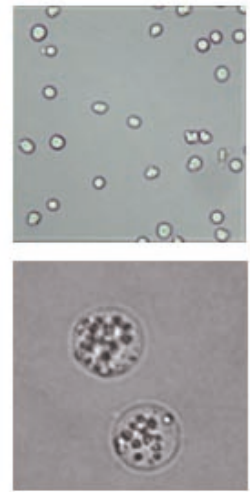

Figure 2. Effect of 2,3-diGGA on HL-60 cells in the presence of $10 \%$ FBS.

HL-60 cells $\left(1.0 \times 10^{5}\right.$ cells $\left./ \mathrm{ml}\right)$ in RPMI 1640 medium containing 10\% FBS were treated with ATRA (100 nM), GGA (10 $\mu \mathrm{M})$, or 2,3 -diGGA $(40 \mu \mathrm{M})$ at $37^{\circ} \mathrm{C}$ for five days under an atmosphere of $5 \%$ $\mathrm{CO}_{2}$. Cell proliferation was monitored with the cell number, and the differentiation to neutrophils was estimated by NBT reduction assay as described under Experimental Procedure. Magnified cells without NBT reduction assay are shown in the lower row.
Analysis of caspase-3 activity. After incubation, the cell suspension was centrifuged at $1000 \times$ $g$ for $10 \mathrm{~min}$. The recovered cells were incubated in $50 \mu \mathrm{l}$ of lysis buffer at $4^{\circ} \mathrm{C}$ for $10 \mathrm{~min}$ and centrifuged at $18000 \times g$ for $3 \mathrm{~min}$. The supernatant $(40$ $\mu \mathrm{l})$ was mixed with reaction buffer $(40 \mu \mathrm{l})$ containing $1 \mu \mathrm{M}$ of caspase-3 substrate (DEVD-pNA) and incubated at $37^{\circ} \mathrm{C}$ for $1 \mathrm{~h}$. Detection of $p$-nitroaniline (pNA) was performed at $405 \mathrm{~nm}$. One unit was defined as the amount of enzyme required to release 1 nmol pNA per $1 \mathrm{~h}$ at $37^{\circ} \mathrm{C}$.

Protein determination. Protein was determined by the Bradford method with Protein Assay Kit (Bio-Rad Laboratories, Inc.) using BSA as a standard.

\section{RESULTS}

Effects of GGA and 2,3-diGGA on HL-60 cells in the presence of $10 \%$ FBS

We examined anti-proliferative effects of alltrans-retinoic acid (ATRA), GGA, and 2,3-diGGA on HL-60 cells in the presence of $10 \%$ FBS. These compounds repressed the proliferation with $\mathrm{EC}_{50}$ of $100 \mathrm{nM}, 10 \mu \mathrm{M}$, and $40 \mu \mathrm{M}$, respectively. When the repressed cells were subjected to NBT reduction assay (Fig. 2), blue colored-cells were detected in the case of ATRA and GGA treatment, indicating that they are neutrophils. No blue color was observed in 2,3-diGGA-treated cells. However, many droplets were detected inside the cells under the microscope. Figure 3 shows cells treated with GGA or 2,3-diGGA at the concentration of 40 $\mu \mathrm{M}$ for 5 days. The droplets detected in the case of 2,3-diGGA treatment were stained with Nile Red, suggesting that they are lipid droplets. We confirmed that these droplets are in fact lipid droplets by silica-gel thin-layer chromatography and enzymatic assay of isolated droplets (see further). These results suggest that GGA acts as an agonist for RAR or RXR, similarly to ATRA, resulting in the differentiation of HL-60 cells to neutrophils and 2,3-diGGA acts as an inducer for the formation of lipid droplets inside the cells.

Effects of GGA and 2,3-diGGA on HL-60 cells in the presence of $0.1 \%$ FBS

When HL-60 cells were treated with 2,3diGGA at various concentrations up to $30 \mu \mathrm{M}$ for

$$
+ \text { GGA }(40 \mu \mathrm{M}) \quad+2,3-\mathrm{DiGGA}(40 \mu \mathrm{M})
$$

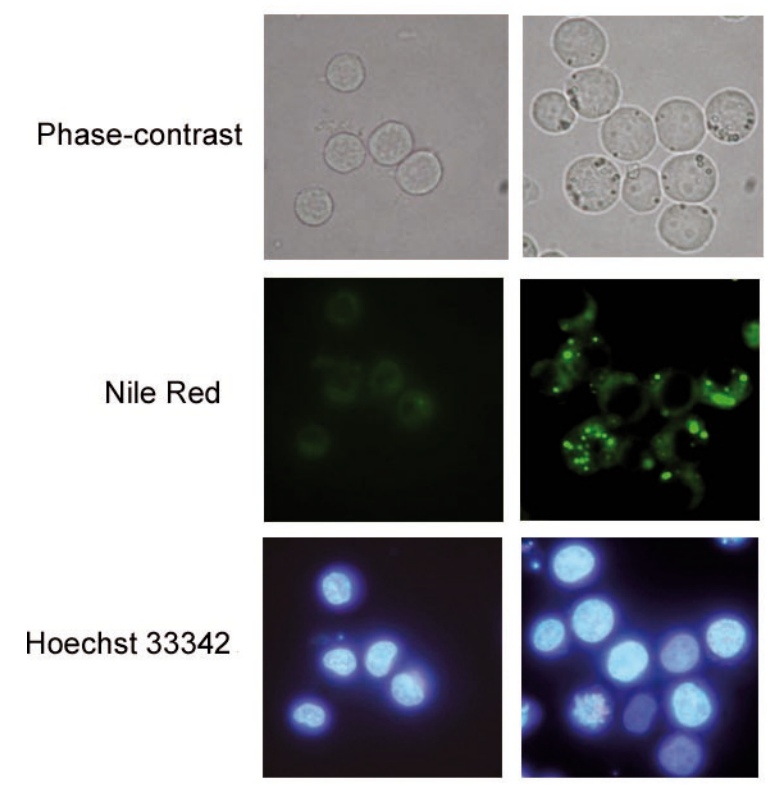

Figure 3. Detection of 2,3-diGGA-induced lipid droplets with Nile Red.

HL-60 cells $\left(1.0 \times 10^{5}\right.$ cells/ml) in RPMI 1640 medium containing $10 \%$ FBS were treated with GGA $(40 \mu \mathrm{M})$ or $2,3-$ diGGA $(40 \mu \mathrm{M})$ for 5 days, stained with $1 \mathrm{mM}$ Nile Red for $2 \mathrm{~h}$ and with Hoechst 33342, and then analyzed by phase-contrast and fluorescence microscopy. 


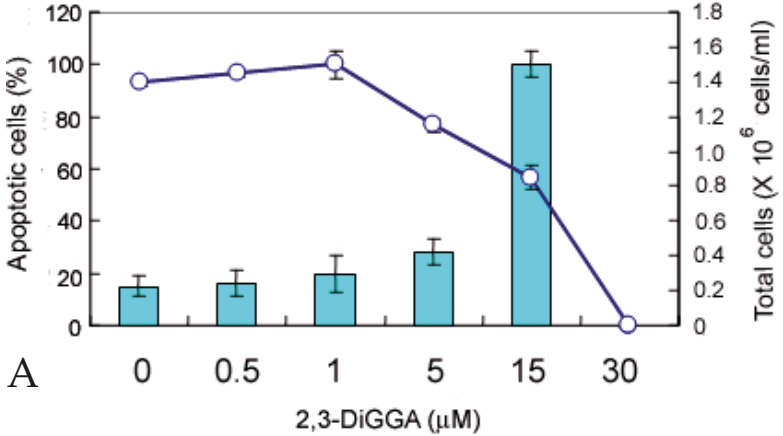

B

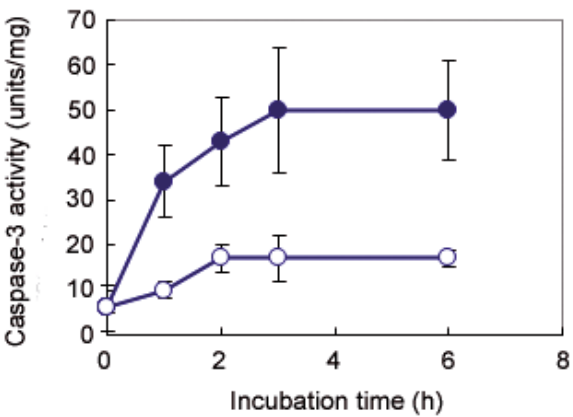

Figure 4. Effect of 2,3-diGGA on HL-60 cells in the presence of $0.1 \%$ FBS.

A. HL-60 cells $\left(1.5 \times 10^{6}\right.$ cells/ml $)$ in RPMI 1640 medium containing $0.1 \%$ FBS were treated with $15 \mu \mathrm{M}$ 2,3-diGGA at $37^{\circ} \mathrm{C}$ for $2 \mathrm{~h}$ under an atmosphere of $5 \% \mathrm{CO}_{2}$, stained with Hoechst 33342, and analyzed with a Zeiss fluorescence microscope. B. HL-60 cells $\left(2.0 \times 10^{6}\right.$ cells $\left./ \mathrm{ml}\right)$ in RPMI 1640 medium containing 0.1\% FBS were treated with $15 \mu \mathrm{M} 2,3$-diGGA at $37^{\circ} \mathrm{C}$ for $0,1,2,3$, and $6 \mathrm{~h}$ under an atmosphere of $5 \% \mathrm{CO}_{2}$. The cells were collected and lysed, and the supernatant was used for caspase- 3 assay as described under Experimental Procedures.

two hours in the presence of $0.1 \%$ FBS, they gradually lysed in a concentration-dependent manner
(Fig. 4A). About a half of the cells lysed at $15 \mu \mathrm{M}$, and no cells were observed at $30 \mu \mathrm{M}$. The DNA fragmentation of the cells was confirmed by agarose gel electrophoresis (not shown). Activation of caspase-3 was also detected in the cells in a time-dependent manner (Fig. 4B). In the case of GGA treatment, the results were similar to those of 2,3-diGGA treatment. These results suggest that GGA and 2,3-diGGA have the ability to induce apoptosis in HL-60 cells in the presence of $0.1 \%$ FBS.

Repression of 2,3-diGGA-induced apoptosis in $0.1 \%$ FBS by Ac-DMQD-CHO

We tried to preincubate the cells in $0.1 \%$ FBS with or without a caspase-3 inhibitor $(100 \mu \mathrm{M}$ AcDMQD-CHO) for $9 \mathrm{~h}$ and then incubated them with $15 \mu \mathrm{M}$ 2,3-diGGA for $20 \mathrm{~h}$. As shown in Fig. 5, apoptotic cells were not observed in the case of the inhibitor alone or in the case of $15 \mu \mathrm{M}$ 2,3-diGGA alone, as expected. However, lipid droplets-containing cells were observed in the case of combination of Ac-DMQD-CHO and 2,3-diGGA. These results suggest that the 2,3-diGGA-induced formation of lipid droplets is independent of the 2,3-diGGA-induced apoptosis.

\section{Lipid analysis of cells containing lipid droplets}

HL-60 cells were treated with $40 \mu \mathrm{M}$ 2,3diGGA for 5 days and extracted with chloroform/ methanol $(2: 1, \mathrm{v} / \mathrm{v})$. Thin-layer chromatography of the extracts showed that TAG and cholesterol were detected in increased amounts. The lipid content of the extracts was also quantitatively analyzed by enzymatic methods. The TAG content was 10 -fold higher than that of control cells, and cholesterol and choline-containing phospholipid contents were

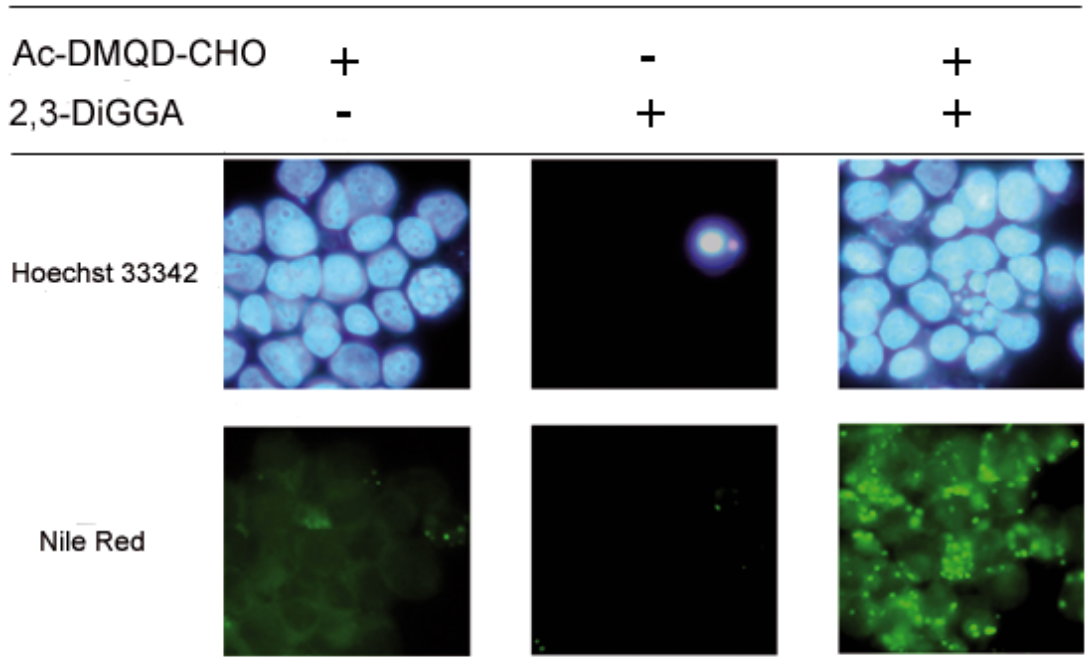

Figure 5. Effect of Ac-DMQDCHO on 2,3-diGGA-induced apoptosis in $0.1 \%$ FBS.

HL-60 cells $\left(1.5 \times 10^{6}\right.$ cells $/ \mathrm{ml}$ were preincubaed with or without $100 \mu \mathrm{M}$ caspase-3 inhibitor, Ac-DMQD-CHO, for $9 \mathrm{~h}$ in $0.1 \%$ FBS and treated with $15 \mu \mathrm{M}$ 2,3-diGGA for $20 \mathrm{~h}$. Cells were analyzed by fluorescence microscopy. 
also two-fold higher. These results indicate that the formation of lipid droplets induced by 2,3-diGGA is accompanied by elevated amounts of TAG and by slightly increased amounts of cholesterol and choline-containing phospholipids.

\section{DISCUSSION}

The aim of our study was to learn whether GGA and 2,3-diGGA are different from each other with respect to their action on cells. Both compounds induced similar apoptosis in the presence of $0.1 \%$ FBS, but showed different effects in the presence of $10 \%$ FBS. GGA induced the differentiation of HL-60 cells into neutrophils, whereas 2,3-diGGA induced the formation of lipid droplets inside the cells. Since GGA and $(R, S)$-2,3-diGGA have been reported to be positive and negative, respectively, in chloramphenicol acetyltransferase (CAT) assays with RARE/CAT or RXRE/CAT plasmids (Araki et al., 1995), it is not surprising that GGA induced the differentiation of HL-60 cells into neutrophils. However, the 2,3diGGA-induced lipid droplet formation was an unexpected finding. It should be noted that the different phenomena are attributed to the $\alpha$-saturated or $\alpha$-unsaturated isoprenyl part of the two isoprenoid acids. The $\Delta-2,3$-double bond might hinder GGA to be used as a substrate for any step(s) of triglyceride synthesis.

Two phenomena, the formation of neutral lipid droplets and apoptotic induction, induced by polyunsaturated and monounsaturated fatty acids have been known and their relationship has been explained through a mechanism of protection against free fatty acid-induced apoptosis (Shimabukuro et al., 1998; Wolfrum et al., 2001; Healy et al., 2003). As the present study shows, two similar phenomena were observed by using 2,3-diGGA. Probably, 2,3-diGGA, similar to unsaturated fatty acids, is also a toxic carboxylic acid and therefore might be metabolized to TAG by detoxication, resulting in the formation of lipid droplets.

Yamakawa-Karakida et al. (2002) have recently reported that human leukemic cell lines including HL-60 cells express PPAR- $\gamma 2$ and that its activation by a natural ligand (15-deoxy- $\Delta^{12,14}-\mathrm{PGJ}_{2}$ ) or by a synthetic ligand (troglitazone) profoundly inhibited their proliferation by the induction of apoptosis preferentially in a serum-free culture. This finding is quite similar to our finding with respect to the apoptotic induction by 2,3-diGGA in the presence of $0.1 \%$ FBS. As shown in Fig. 5, when the 2,3-diGGA-induced apoptosis was repressed through caspase-3 inhibition, lipid droplets were induced. However, it remains unclear if 2,3-diGGA in fact acts on some nuclear receptor such as
PPAR- $\gamma 2$, resulting in increased formation of lipid droplets. Further studies using dominant negative nuclear receptors and additional studies to determine the chemical nature of TAG induced by 2,3diGGA are in progress.

\section{Acknowledgements}

This work was supported in part by a Grandin-Aid from the Ministry of Education, Culture, Sports, Science, and Technology of Japan.

\section{REFERENCES}

Appella DH, Moritani Y, Shintani R, Ferreira EM, Buchwald SL (1999) Asymmetric conjugate reduction of $\alpha, \beta$-unsaturated esters using a chiral phosphine-copper catalyst. Am Chem Soc 121: 9473-9474.

Araki H, Shidoji Y, Yamada Y, Moriwaki H, Muto Y (1995) Retinoid agonist activities of synthesis geranylgeranoic acid derivatives. Biochem Biophys Res Commun 209: 6672.

Bligh EG, Dyer WJ (1959) A rapid method of total lipid extraction and purification. Can J Biochem Physiol 37: 911-917.

Breitman TR, Selonick SE, Collins SJ (1980) Induction of differentiation of the human promyelocytic leukemia cell line. Proc Natl Acad Sci USA 77: 2936-2940.

Christophe J, Popjak G (1964) Studies on the biosynthesis of cholesterol: XIV the origin of prenoic acids from allyl pyrophosphates in liver enzyme systems. J Lipid Res 2: 244-257.

Crick DC, Andres DA, Waechter CD (1997) Pathway utilizing farnesol and geranylgeraniol for protein isoprenylation. Biochem Biophys Res Commun 237: 483-487.

Dituri F, Rabinowitz JL, Hullin RP, Gurin S (1957) Precusors of squalene and cholesterol. J Biol Chem 229: 825836.

Fliesler SJ, Schroepfer GJ (1983) Metabolism of mevalonic acid in cell-free homogenates of bovine retinas. Formation of novel isoprenoid acids. J Biol Chem 258: 1506215070.

Forman BM, Ruan B, Chen J, Schroepfer GJ, Evans RM (1997) The orphan nuclear receptor LXR $\alpha$ is positively and negatively regulated by distinct products of mevalonate metabolism. Proc Natl Acad Sci USA 94: 10588-10593.

Goldstein JL, Brown MS (1990) Regulation of the mevalonate pathway. Nature 343: 425-430.

Gonzalez-Pacanowska D, Arison B, Havel CM, Watson JA (1988) Isopentenoid synthesis in isolated embryonic Drosophila cells. Farnesol catabolism and $\omega$-oxidation. J Biol Chem 263: 1301-1306.

Healy DA, Watson RWG, Newsholme P (2003) Polyunsaturated and monounsaturated fatty acids increase neutral lipid accumulation caspase activation and apoptosis in a neutrophil-like differentiated HL-60 cell line. Cli Sci 104: 171-179.

Kodaira Y, Usui K, Kon I, Sagami H (2002) Formation of (R)-2,3-dihydrogeranylgeranoic acid from geranylgeraniol in rat thymotcytes. J Biochem 132: 327-334.

Morjani H, Aouali N, Belhoussine R, Veldman RJ, Levade T, Manfait M (2001) Elevation of glucosylceramide in multidrug-resistant cancer cells and accumulation in cytoplasmic droplets. Int J Cancer 94: 157-165. 
Popjak G (1959) The biosynthesis of derivatives of allylic alcohols from $\left[2-{ }^{14} \mathrm{C}\right] \mathrm{mevalonate}$ in liver enzyme preparations and their relation to synthesis of squalene. Tetrahedron Lett 19-28.

Shidoji Y, Nakamura N, Moriwaki H, Muto Y (1997) Rapid loss in the mitochondorial membrane potential during geranylgeranoic acid-induced apoptosis. Biochem Biophys Res Commun 230: 58-63.

Shimabukuro M, ZhouY-T, Levi M, Unger RH (1998) Fatty acid-induced $\beta$ cell apoptosis: a link between obesity and diabetes. Proc Natl Acad Sci USA 95: 2489-2502.

Wang X, Wu J, Shidoji Y, Muto Y, Ohishi N, Yagi K, Ikegamo S, Shinki T, Udagawa N, Suda T, Ishimi Y (2002) Effects of geranylgeranoic acid in bone: induction of osteoblast differentiation and inhibition of osteoclast formation. J Bone Miner Res 17: 91-100.
Wolfrum C, Borrmann CM, Borchers T, Spener F (2001) Fatty acids and hypolipidemic drugs regulate peroxisome proliferator-activated receptors $\alpha$ - and $\gamma$-mediated gene expression via liver fatty acid binding protein: a signaling path to the nucleus. Proc Natl Acad Sci USA 98: 2323-2328.

Yamakawa-Karakida N, Sugita K, Inukai T, Goi K, Nakamura M, Uno K, Sato H, Kagami K, Barker N, Nakazawa S (2002) Ligand activation of peroxisome proliferators-activated receptor gamma induces apoptosis of leukemia cells by down-regulating the $c$-myc gene expression via blockade of Tcf-4 activity. Cell Death Differ 9: 513-526. 